\title{
Student Views about the Public Spot Advertisement Signs in the Context of Lifelong Learning (The Example of Reading Culture Themed Public Spot Advertisement)
}

\author{
H. Altuğ Tanca ${ }^{1} \&$ Fatma Ünal ${ }^{2}$ \\ ${ }^{1}$ Department of Information Technologies, Bartın University, Bartın, Turkey \\ ${ }^{2}$ Faculty of Education, Bartın University, Bartın, Turkey \\ Correspondence: H. Altuğ Tanca, Department of Information Technologies, Bartın University, Bartın, 74100, \\ Turkey. E-mail: altugtanca@hotmail.com ORCID: https://orcid.org/0000-0002-0453-3782
}

$\begin{aligned} & \text { Received: November 21, } 2017 \quad \text { Accepted: December 13, 2017 Online Published: December 21, } 2017 \\ & \text { doi:10.5539/jel.v7n2p100 }\end{aligned}$ URL: http://doi.org/10.5539/jel.v7n2p100

\begin{abstract}
It's important that the messages and information in the public spot advertisements that is wanted to be conveyed to the individuals to be reached at the desired level and an asymmetric structure existing between the message prepared with a fictional structure and the perception between the message and the receiving party. Because, a decent perceptional connection between the receiving party and the fictionalized message shows the message has reached its purpose normally. From this angle, there's an important connection between the public spot advertisements which has the purpose of creating a common consciousness and the concept of lifelong learning. In this research it's aimed that the student views about lifelong learning and public spot advertising signs in the example of "Reading Culture Themed Public Spot Advertisement" to be examined. In the research phenomenology which is one of the qualitative research patterns has been used. The working group has been established with the method of criterion sampling and a research has been conducted with 9 volunteering participants. For data collection interview forms have been used and the data has been analysed with the method of descriptive analysis. In the research, it has been revived that public spot advertisements contribute to the lifelong learning of the participants. As a result of the analysis conducted in the research, the themes of lifelong learning, education-themed public spot advertisements, acquirement of lifelong learning experience and its contribution to the educational process, sharing, attitudes, visual coding, book-reading, attention and slogans have been arisen. In the research, significant differences haven't occurred between positive and negative views of the participants according to the slogans broadcasted at the end of the public spot advertisements, however it's been determined that there are positive critical approaches that the slogans are successfully conveying the messages expected to be given. More public spot advertisements to be prepared and working on social awareness on this subject has been suggested.
\end{abstract}

Keywords: lifelong learning, public spot advertisement, public service announcement, education

\section{Introduction}

The existence form of the individuals are shaped with social situations. It's a general mistake that this change starts at birth. The consciousness, awareness and the quality of life of the mother has a great effect on the born individual. Not only physiological effects, but the psychological development also has importance on the bond between the mother and her baby. The stress, low quality and standards of life the mother endures is the cause of the baby getting affected as well. Attachment to a baby during pregnancy expresses the pregnant woman's emotions towards her unborn baby, her interaction with it and defining herself as a mother during pregnancy, hence the process of developing her identity as a mother (Duyan, Kapısız, \& Yakut, 2013, p. 1610). This bond starts to form before the individual is born and it continues to take shape after that. This consecutive interaction effects both the individual's personality and his/her personal skills and point of view. The learning process continues through life and the achievements are handed down to next generations. The concept of lifelong learning points to the person's achievements in individual meaning. These achievements, despite being individual, also have the purpose of shaping the social living.

The fast progress of technology causes the increasing of the problems about the subject. The knowledge and 
skills acquired during formal education becoming insufficient in the competition-driven business market, causes increasing problems concerning employment. One of the first documents on lifelong learning, has been prepared with the title "Learning to be. The world of education today and tomorrow" by the International Commission on the Development of Education to United Nations Educational, Scientific and Cultural Organization (UNESCO) in 1972 (Steffens, 2015, p. 41). This commission was chaired by Edgar Faure and this report was named as the Faure Report (Elfret, 2015, p. 88). Güleç, Çelik, \& Demirhan (2012, p. 35) define lifelong learning as accepted by UNESCO in 1970's and along with it in 1970's and 1980's, Organisation for Economic Co-operation and Development's (OECD) educators' and educational policy-makers' acceptance by associating it with continuous education, and state that non-formal education lacks satisfying the needs. According to the World Bank (2003, XVII), the definition that a lifelong learning framework encompasses learning throughout the lifecycle, from early childhood through retirement, encompassing formal learning (schools, training institutions, universities); nonformal learning (structured on-the job training); and informal learning (skills learned from family members or people in the community). The concepts of informal education and non-formal education out of formal education provide the achievement of contemporary vocational skills, behaviours regulating social living and awareness in personal and global level. According to Steffens (2015, p. 43) one of the most recent developments in the field of learning with digital technologies is Massive Open Online Courses (MOOCs) and it's stated that it is a relatively new development and it is certainly too early to say something definite about their potential to enhance learning. Along with that, advertising produces in order to affect the masses via the television and the Internet, affects the lives, learning and behaviours out of formal education and in short, has an important part in the process of lifelong learning.

Advertising has been born by the start of first activities of purchasing or bartering (Tayfur, 2008, p. 5). The people have started to highlight the characteristics and the advantages of their products and/or services, sell and raise prices of them. After the printing press was invented in the 15th century, the advertising hung by William Caxton on the door of a church in London, advertising for the books he sells, is the first wall poster (MEGEP, 2007, p. 10).

Public spot advertisements as a kind of advertising, are classified according to some situations while they are prepared. Tayfur (2008, pp. 38-42) has classified advertisements as; from the angle of the ones producing the advertisements, from the angle of the target audience, from the angle of the demand, from the angle of the subject, from the angle of the message, from the angle of the payment, from the geographic angle, advertising with a social purpose, advertising according to communication means, and according to the applied strategy main titles. During the advertisement's preparation period the target audience, the purposes, the theme, the message and the likewise problems should be answered. Thus, the success of the advertisements is possible by giving the correct answers to the questions and sub-questions asked by those titles.

According to Ertike (2009, p. 22), strategically advertising consists of the formula defined as AIDA which was coined by the capital letters of the words attention, interest, desire and action. The advertisement should attract the attention of the target audience, arise interest in the target audience, a desire should arise for the object and/or the subject of the advertising in the target and finally get the target audience in action. However the discipline, which was under the influence of the changing dynamics, name the formula as its contemporary name NAIDAS by adding need at the beginning and satisfaction at the end of the process. In order to attract the attention of the target audience, first the target audience is made to believe that it needs the subject and if the aforementioned subject is applied by the target audience, it will feel satisfaction (Ertike, 2009, pp. 22-23). According to Elden (2009, pp. 393-395), in advertising Maslow's hierarchy of needs theory is being used to lead the needs groups, target audience's behaviours and produce an attractive content. According to Maslow's hierarchy of needs, concerning our humanly demands in the hierarchical order if the need on a higher level of priority isn't satisfied, the realization of the lower levels is difficult. The concept of need at the beginning of the formula NAIDAS gets importance in this context.

Public spot advertisements are produced by institutions, organizations and/or associations, by themselves or by collaboration, with concerns over social responsibility, with the themes of health, education, national values, protecting the environment, civic rights, etc. (Yaman \& Göçkan, 2015, p. 56). Public spot advertising is also expressed as announcement concerning public service, public service announcement (PSA's), social marketing, social commercial and government commercial. Advertisements with social purposes which are aimed at providing a certain idea, produced by for-profit or non-profit organizations in order to increase the welfare of the society are under this group (Tayfur, 2008, p. 41). Organizations like the Green Crescent, producing advertisements which warn the people of the harm caused by alcohol, or a fuel company running an advertisement campaign which conveys warning messages on traffic accidents are two good examples on social 
advertising.

It's important that the messages and information in the spots that is wanted to be conveyed to the individuals reaching the target audience at the desired level and an asymmetric structure existing between the message prepared with a fictional structure and the perception between the message and the receiving party. Because, a decent perceptional connection between the receiving party and the fictionalized message shows the message has reached its purpose normally. For this reason, it's thought that there's an important connection between the public spot advertisements which has the purpose of creating a common consciousness and the concept of lifelong learning. In this research it's aimed that the student views about lifelong learning and public spot advertising signs in the example of "Reading Culture Themed Public Spot Advertisement" to be examined. According to this purpose, in the research answers have been sought for the question "What are the undergraduate students' views about the contribution of public spot advertisements to lifelong learning and the signs concerning educational themed public spot advertisements?".

\section{Method}

\subsection{The Model of the Research}

In the research, phenomenology, one of the qualitative research patterns, has been used. The philosophy of phenomenology focuses on the experience itself and how experience turns something into awareness and conducts interviews on searching for the basic structure or the reality under the experience (Merriam, 2013, pp. 24-25). The reason for using phenomenology in this research is, to deeply examine the existing phenomena. Phenomenology examines the phenomena which we aware of, without a deep, detailed knowledge (Yildırım \& Şimşek, 2014). The data collection device which is used for existing phenomenons and experiences is mainly the interview. With this purpose, in this research, semi-structured interview forms are used. Student views on lifelong learning and public spot advertising signs, using the example "Reading culture themed public spot advertisement".

\subsection{Working Group}

11 volunteering undergraduate students selected by criterion sampling have made up the working group of the research. Criterion sampling is the research method by using a certain series of criteria or a certain criterion determined by the researcher (Yıldırım \& Şimşek, 2014, p. 140). In the research, the criteria of participating willingly and watching public spot advertising have been used. With one participant, a pre-application of the data collection tool has been made and the data acquired was not included in the analysis. As the interview with one participant was interrupted, it was left out of the research with the consent of the participant. For this reason, in the analysis of the research data collected from 9 participants has been used. Among the students participating in the research, 4 are female and 5 are male.

\subsection{Data Collection Tool and Collection of Data}

With the form prepared by the researchers, it is aimed that revealing the participants' knowledge, views and suggestions concerning lifelong learning, public spot advertising and "Book reading culture" themed public spot advertisement and explaining the relationships between the subjects.

In order to determine the content validity of the data collection tool, expert opinion has been consulted. A presentation has been made to five academics, whom are experts on their fields. Opinions have been asked from different experts from the disciplines of educational sciences, lifelong learning and communications. According to these opinions, a variety of arrangements have been applied on the form prepared.

Ten questions for the interview form according to the findings at the end of literature scanning within the disciplines of lifelong learning, communications, education and social sciences have been prepared, taking expert opinion. The prepared questions have been applied in an interview for testing and have been corrected for the sake of consistency and clarity. Nine finalized interview questions are asked to the 11 users respectively. Before the questions are answered, the "book reading culture" themed public spot advertising produced by the National Ministry of Education, has been shown to the participants. The replies by the participants have been recorded with sound-recording devices. Each interview lasted approximately 30 minutes.

\subsection{Analysis of the Data}

After the interviews, the sound recordings have been deciphered and converted into a text. The deciphering has been made by two people in different times and the acquired texts have been compared. The data collected from the interviews has been evaluated by the method of descriptive analysis. In descriptive analysis the data is summarized and interpreted according to the previously determined themes. The data may be organized 
according to the themes that the research questions revive or considering the questions or the dimensions used in the processes of interviews and observation. A descriptive analysis has four phases. Those are: forming a framework for descriptive analysis, processing of the data according to the thematic framework, description and interpretation of the findings (Yıldırım \& Şimşek, 2014, pp. 224-225). In this study, based on literature, a framework has been formed for data analysis. The themes have been organized according to the research questions, in order to reflect the individuals' views, descriptions have been made by giving direct quotes and interpreted by the researcher, considering the literature. The same texts have been examined by another researcher once again according to .the validity and reliability of the research and the statements of the researchers and analysis results have been compared. The findings have been written by the common decision of the researchers. In order to keep the identities of the students whose views have been referenced secret, the interviewees were coded as P1, P2, P3... and their answers have been quoted.

\section{Findings and Comments}

In this section, along with the example of "Reading Culture Themed Public Spot Advertisement", student views according to lifelong learning and public spot advertising signs, have been presented according to the themes. As a result of the analysis conducted in the research, the themes of lifelong learning, education-themed public spot advertisements, acquirement of lifelong learning experience and its contribution to the educational process, sharing, attitudes, visual coding, book-reading, attention and slogans have been arisen.

\subsection{Lifelong Learning}

The participants are asked the question: "Do you think public spot advertisements contribute to your lifelong learning? Why?" With this question, the participants' knowledge about the concept of lifelong learning has been tested and examining their awareness on their learning situation has been aimed. The answers given to the question and their distribution according to their coding have been shown in Table 1.

Table 1. Distribution of the answers given to the question "Do you think public spot advertisements contribute to your lifelong learning? Why?" according to their coding

\begin{tabular}{lll}
\hline Theme & Frequency (f) & Descriptions According to Coding \\
\hline & 5 & Accessibility by mass media \\
3 & Contribution to knowledge \\
Lifelong learning & 2 & Easy remembrance \\
& 2 & Being educative \\
& 1 & Raising awareness \\
& 1 & Being impressive \\
\hline
\end{tabular}

When the participants' answers on Table 1 are generally evaluated, positive views on public spot advertisements being accessible by mass media are stated. The participants are stating that the contribution to public spot advertisements to lifelong learning are realized by their accessibility by mass media (5), their contribution to knowledge (3), their easy remembrance (2), they being educative (2), their raising awareness (1) and being impressive (1). There have been 8 interviewees that think public spot advertisements have contribution to lifelong learning, while 1 interviewee has expressed a negative view and says that s/he doesn't agree.

Sample sentences according to the answers the participants give to the question are shown below.

P1: "They enter through the people's minds via television and other media channels."

P5: "...by television they reach all ages."

P8: “... as they are more common on television, internet media and cyberspace and these media are more widely used, they can reach everyone."

\subsection{Education Themed Public Spot Advertisements}

The question: "Do you find the education themed public spot advertisements sufficient? Why?" has been asked the participants. With this question, the aim is, to examine the sufficiency of education themed public spot advertisements that are broadcasted by asking the views of participants on education themed public spot advertisements. The answers given to the question and their distribution according to their coding have been shown in Table 2. 
Table 2. Distribution of the answers given to the question "Do you find the education themed public spot advertisements sufficient? Why?" according to their coding

\begin{tabular}{llll}
\hline Theme & & Frequency (f) & Descriptions According to Coding \\
\hline \multirow{2}{*}{$\begin{array}{l}\text { Education themed public spot } \\
\text { advertisements }\end{array}$} & & 1 & Not encountering and being few in number \\
& & 1 & Not attention grabbing \\
\hline
\end{tabular}

When the answers given by the participants on Table 2 are evaluated, with the descriptions of not encountering public spot advertisements and they being few in number (5), public spot advertisements not grabbing attention (1) and public spot advertisements being expected to be improved (1) seven participants whom consist of three female and four male participants having negative views have been seen and the participants have stated that they find education themed public spot advertisements insufficient.

Sample sentences according to the answers the participants give to the question are shown below.

P2: "Encounter rate is low."

P4: "I think that education themed public spot advertisements must be more."

P8: "If it doesn't grab my attention, it's insufficient."

\subsection{Acquirement of Lifelong Learning Experience and Its Contribution to the Educational Process}

The questions "Do you think the educational knowledge in the public spot advertisements give you a lifelong learning experience? What are their contribution to your lifelong learning process in life? Please explain" have been asked. With these questions, the participants' views on their gains from the public spot advertisements' contribution to their lifelong learning experience and the learning process. Examination of functionality situation of the theme in the context of public spot advertising has been aimed. The distribution of the answers to these questions according to their coding has been shown in Table 3 .

Table 3. Distribution of the answers given to the question "Do you think the educational knowledge in the public spot advertisements give you a lifelong learning experience? What are their contribution to your lifelong learning process in life? Please explain." according to their coding

\begin{tabular}{lll}
\hline Theme & Frequency (f) & Descriptions According to Coding \\
\hline Acquirement of Lifelong Learning Experience and & 4 & Don't provide gains \\
Its Contribution to the Educational Process & 4 & Provide gains \\
\hline
\end{tabular}

When the answers given by the participants on Table 3 are evaluated, equally distributed views have been seen. In the views revived in the descriptions according to the coding of the theme, no groupings and common views have been encountered. The views are expressed with these situations: Not encountering with public spot advertisements, their not being educational, their not giving experience, their only raising of awareness and being broadcasted more.

Sample sentences according to the answers the participants give to the question are shown below.

P2: “... as I encounter few, I think don't.”

P4: "I don't really think that public spot advertisements are educational."

P5: "Only helpful in the dimension of awareness"

P9: “... everything is forgotten, thus they should be brought up more."

\subsection{Sharing}

The questions: "Do you share the knowledge and information you learn from public spot advertisements with your family and friends? Which ones do you share most? Please explain with examples." have been asked to the participants. With these questions, the aim was to learn what the situation of the participants about sharing the public spot advertisements they have watched were and what kind of public spot advertisements they prefer to share. With this, it's been aimed to acquire information on the preferences of the participants. The distribution of the answers to these questions according to their coding has been shown in Table 4. 
Table 4. Distribution of the answers given to the question "Do you share the knowledge and information you learn from public spot advertisements with your family and friends? Which ones do you share most? Please explain with examples." according to their coding

\begin{tabular}{lll}
\hline Theme & Frequency (f) & Descriptions According to Coding \\
\hline \multirow{3}{*}{ Sharing } & 6 & Topics of health and smoking \\
& 2 & Topics of environment and nature \\
& 1 & Not remembered \\
1 & Education \\
\hline
\end{tabular}

The descriptions according to the coding which was formed according to the answers that participants have given on the theme of sharing on Table 4 have been expressed to be topics of health and smoking (6), topics of environment and nature (2), not being remembered (1) and lastly, education (1). Eight of the answers had positive views that the public spot advertisements were shared while one participant expresses a negative view because they were not remembered. It's been observed that the participants prefer to share the topics of health and smoking more and topics of education least among the public spot advertisement topics. The participants indicate in their views that the reasons to show the public spot advertisements they watch is the comedic element, or that they prefer sharing the public spot advertisements connected to their field.

Sample sentences according to the answers the participants give to the question are shown below.

P2: "It would be better if they were more, more easily remembered."

P3: "Again, most probably a smoking related public spot advertising, just the parts I found funny."

P4: "As a forester, I share the public spot advertisements on nature with a circle I find close and sincere"

P7: "And again another smoking public spot advertisement: there, as a little bit of a joke among us..."

\subsection{Attitudes}

The questions "What are your thoughts and views on public spot advertisements? Please explain the positive and negative aspects." have been asked to the participants. With those questions, taking the participants' attitudes and views on public spot advertisements has been aimed. The distribution of the answers to these questions according to their coding has been shown in Table 5 .

Table 5. Distribution of the answers given to the question "What are your thoughts and views on public spot advertisements? Please explain the positive and negative aspects." according to their coding

\begin{tabular}{lll}
\hline Theme & Frequency (f) & Descriptions According to Coding \\
\hline & 3 & Being awareness-raising \\
Attitudes & 3 & Being informative and educative \\
& 2 & Being accessible \\
& 2 & Being few \\
6 & Others* \\
\hline
\end{tabular}

Note. *: Positive effect from the environment (1), negative effect from the advert (1), realism (1), statement of unawareness(1), lack of different media usage (1), having positive topics (1)

When the answers given by the participants on Table 5 are evaluated, it's been determined that seven positive and two negative answers were given. Despite the participants' views on public spot advertising being generally positive, they have often expressed views on the insufficiencies of public spot advertisements. It's seen that the participants often have common views that public spot advertisements are awareness-raising, informative and educative. Views that they are being few in number for its widespread usage and different media outlets are not being used. Among these views the view of "statement of unawareness" is semantically different and draws attention among others.

Sample sentences according to the answers the participants give to the question are shown below.

P3: “. .. if they were more relevant to our lives, more detailed, more realistic; maybe they could be a little beneficial..."

P4: "It's a positive aspect that they raise awareness in public."

P5: “... just not on television, but maybe as a placard when we're walking on the road." 
P6: "Well, it's the sign of our personality or unawareness is on the background."

\subsection{Visual Coding}

The questions: "In the public spot advertisement that's prepared by the National Ministry of Education about reading habits, a woman and a child are reading a book in bed. How do you define the relationship between the woman and the child? Please explain why you think that way." have been asked. With this question, the aim was to understand how and according to what variables do the participants code the actors' roles in the scenes. How the signs in the scene are defined by the audience is important in terms of defining the relation between the message, what is shown, the sign and the interpreted message. In this context, the theme of visual coding has been separated in two under the subheadings of relationship and reason and has been presented on Table 6 .

Table 6. Distribution of the answers given to the question: "In the public spot advertisement that's prepared by the National Ministry of Education about reading habits, a woman and a child are reading a book in bed. How do you define the relationship between the woman and the child? Can you explain why you think that?" according to their coding

\begin{tabular}{lcl}
\hline Theme & Frequency (f) & Descriptions According to Coding \\
\hline \multirow{2}{*}{ Visual coding (relationship) } & 7 & Mother and child \\
& 1 & Grandmother-child \\
\hline & 5 & Making people gain a habit \\
Visual coding (reason) & 4 & Generalization \\
& 3 & Identification \\
& 2 & Family education \\
& 1 & No relation \\
\hline
\end{tabular}

When the answers given by the participants on Table 6 six participants have expressed positive views and in the answers given by three participants there hasn't been a positive or negative answer. Among the participants whom express their views, seven people define the relation between the woman and a child as "mother and child", one person defines as "grandmother and grandchild". It's significant that the roles of the actors' roles defined as mother and child. The reasons for the thoughts they are expressing are "making people gain a habit" (5), generalization (4), identification (3), family education (2) and no relation (1). Among the views on reason, the reason for the view "making people gain a habit"; has the purpose of explaining the relationship shown in the actors' roles. In the context of social gender, the judgement that mothers are seen as an educator can be seen as an important reason for this finding.

Sample sentences according to the answers the participants give to the question are shown below.

P1: "My mother would buy a book and come, read, explain."

P2: "Because it's always like that. Generally mothers read books to their children..."

P5: "To a child, his/her mother is closer"

P6: "Actually the mother is persuading her child."

\subsection{Book Reading}

The questions: "In the park, an old man is reading a book. What do you think about the old man reading a book in the park? What kind of impression does it have on you?" have been asked to the participants. With this question, the aim was to have the participants evaluate the ongoing situation in the scene about reading books and to examine if there are significant differences among these evaluations... The distribution of the answers to these questions according to their coding has been shown in Table 7.

Table 7. Distribution of the answers given to the question: "In the park, an old man is reading a book. What do you think about the old man reading a book in the park? What kind of impression does it have on you?" according to their coding

\begin{tabular}{lll}
\hline Theme & Frequency (f) & Descriptions According to Coding \\
\hline \multirow{3}{*}{ Book reading } & 3 & Unrealistic \\
& 2 & Promotive \\
& 1 & Lifelong learning \\
& 1 & Has a subliminal message \\
\hline
\end{tabular}


When the given answers were evaluated, it's seen that three negative and six positive views have been collected. Along with the findings the statements of being unrealistic (3), being promotive (2), expressing lifelong learning (1) and having a subliminal message (1) have been reached. It's significant that all participants with a negative view express that the public spot advertisement they have watched is unrealistic.

Sample sentences according to the answers the participants give to the question are shown below.

P1: “... as I had never seen a book-reading old man before, that scene seemed a bit pretentious for me.”

P5: "He keeps on learning."

P8: "It's very nice as it's an example to the youth, encouraging."

\subsection{Attention}

The questions: "A woman is reading a book in a café. Is there a situation that attract your attention in the scene? What do you think about the woman turning the book's pages in a shorter time than one (1) second? What did you feel? Please explain..." have been asked to participants. The questions asked aim measuring the participants' attention the logical mistake at the café scene of the book reading culture themed public spot advertisement. With that the aim was to examine the attention the participants are paying to the visual texts they are watching. The theme has been examined under two subheadings entitled Awareness and Feeling. The distribution of the answers to these questions according to their coding has been shown in Table 8 .

Table 8. Distribution of the answers given to the questions: "A woman is reading a book in a café. Is there a situation that attract your attention in the scene? What do you think about the woman turning the book's pages in a shorter time than 1 second? What did you feel? Please explain..." according to their coding

\begin{tabular}{lll}
\hline Theme & Frequency (f) & Descriptions According to Coding \\
\hline \multirow{2}{*}{ Book reading (Awareness) } & 8 & Situation not noticed \\
& 1 & Situation noticed \\
\multirow{3}{*}{ Book reading (Feeling) } & 4 & The scene not found believable \\
& 2 & The situation being ignored \\
& 1 & The scene promotes reading \\
& 1 & Makes the audience feel lack of attention \\
\hline
\end{tabular}

When the given answers have been evaluated, it's seen that there are five positive and four negative views. In the awareness level, it's significant that there are eight participants that don't realize the situation while pone participant has realized the logical mistake found in the scene. Four of the participants find the scene believable; two are ignoring what happens in the scene; one person thinks that the scene promotes reading and one participant expresses the view that he has the feeling of lack of attention.

Sample sentences according to the answers the participants give to the question are shown below.

P1: "Right now, I can say that there's a lack of attention."

P5: "There's a guidance to reading books"

P7: “... I'm getting the message on reading books, the rest doesn't interest me."

\subsection{Slogans}

The question "What are your thoughts on the slogans mostly broadcasted at the end of the public spot advertisements?" has been asked to the participants. With this question, the aim was to try to evaluate the effectiveness of the slogans in the public spot advertisements. The distribution of the answers to these questions according to their coding has been shown in Table 9 .

Table 9. Distribution of the answers given to the question "What are your thoughts on the slogans mostly broadcasted at the end of the public spot advertisements?" according to their coding

\begin{tabular}{lll}
\hline Theme & Frequency (f) & Descriptions According to Coding \\
\hline & 5 & They give the message to be conveyed. \\
& 2 & Easily remembered. \\
Slogans & 2 & Should be more effective. \\
& 1 & Not attention-grabbing. \\
& 1 & Slogans are irritating. \\
\hline
\end{tabular}


When the answers are evaluated, it's determined that there have been five positive and four negative views. According to the answers of most participants, the prevalent expression is that, the slogans generally broadcasted at the end of the public spot advertisement convey the necessary message (5). Existence of one person among the participants having the negative view that the slogans broadcasted are irritating is significant for the fact that it's different than other negative views

Sample sentences according to the answers the participants give to the question are shown below.

P5: "... should be more serious and effective."

P6: "Well, it's nice but it hurts my conscience."

P7: "... purpose-driven slogans can convey the message that is wanted to be given across very well.."

P8: "I think that most attention-grabbing part is this."

\section{Discussions, Conclusion and Suggestions}

At the end of the research aimed at examining student views on lifelong learning and public spot advertisement signs in the example of "Reading Culture Themed Public Spot Advertisement"; it's been determined that the participants have positive views on the contribution of public spot advertisements. This situation is supportive of the thought that public spot advertisements are used accordingly with effectiveness. The aforementioned contribution, especially the view that the messages that are wanted to be conveyed to be delivered by mass media and accessible by everyone, is significant. Reaching values of view lower than expected in the context of public spot advertisements being effective and raising awareness, revives the view that public spot advertisements are accessible by everyone, however they are weak at the point of effectiveness and being awareness-raising.

In the research, according to the participants' views on the sufficiency of the public spot advertisements, negative views that express education themed public spot advertisements are insufficient. This situation has been expressed by the participants with descriptions that education themed public spot advertisements are hard to encounter and being few in number. This situation forms a significant difference between the views on the encountering frequency of overall broadcasted public spot advertisements and the education themed public spot advertising in the favor of education themed public spot advertisements. In this context, the view that claims education themed public spot advertisements are qualitatively insufficient has been arisen.

In the research the information in the public spot advertising's effect on the life experiences of participants in the context of lifelong learning has been examined and according to the views of the participants; there's no difference as the views on the gains are distributed equally. However the participants, whom express views on the gains have used critical statements on different insufficiencies of public spot advertisements. This situation has revived the view that by all means, the public spot advertisements contribute to experience in the context of lifelong learning, however they are insufficient.

In the research, according to the participants' likes about public spot advertisements and sharing in that direction, while positive views that they are sharing them in their circles have been stated, it's been revived that the public spot advertisements on the topics of health and smoking is often shared. It's significant that the least shared theme is education. Meanwhile, the reason for sharing the watched public spot advertisement has been stated as the comedic elements of the scenarios and/or absurd situations happening in the public spot advertisements. In this context it's been revived that the comedic elements are attention grabbing and helps the advertisements to be shared more.

In the research, according to the participants' thoughts on public spot advertisements and their views on the positive and negative aspects of public spot advertisements, it's determined that the participants have positive views. It's been observed that the critics by the participants are positive views which are in the direction of public spot advertisements to be awareness-rising, informative, educative and accessible. Çakır \& Çakır (2007) have reached the conclusion that when the advertisement is informative, it effects the advertising attitude directly. However the view stating that public spot advertising is a statement of unawareness is significant. In this context the views worth attention are; concerning public spot advertisements- awareness-raising and concerning the social situation- a statement of unawareness. This situation states how much the society needs awareness. Stokes \& Hull (2002) have stated that public spot advertisements and the topical applications on the subject are educative, informative and improving.

In the research, according to the views of the participants that are about, the setup of the public spot advertising and how the audience imagines, fictionalizes and interprets the public spot advertisements, it's determined that most answers were positive Different from the other answers, one participant has stated that the actors are 
grandmother and grandchild and according to his/her explanation, it's been determined that there was an identification. This situation revives that the audience interprets some visual codes and is in the effort of completing the setup himself/herself. Tower (2000) has determined in his study that television productions use thematic and stereotypical statements with analysing people's sign codes. The sounds formed, the roles played by the actors, camera shots, visual imagery and/or texts lead to the result that the audience interprets the scene with pre-coded information without any dialogue, explanatory expression or text and end up in a common deduction. While the participants mostly give the answer of an adult having a growing child gain a habit, generalization about a social phenomenon and identifications on his/her own life in order, is significant. This situation forms significant expressions on which variables are used with what kind of connection when the person is interpreting the sign. In this context, it's pointed that the persons' method of interpreting signs are realized by their own lives and the sociological effect of the experiences on life and therefore causes reaching the conclusion that the effect of lifelong learning experiences leads to this situation. In the study by Aytekin (2016) it's been stated that the semantic basis of the concepts in the public spot advertisements have been commenced and the public spot advertisements are transformed into a propaganda application, deviating from the aim. The view that the contents of the messages deciphered by sub-cultures tied to the sociological structure by the audience must be carefully analysed, or else there would be results that support the negative aspects of lifelong learning is revived.

In the research, according to the participants' views about the book reading theme in the book reading culture themed public spot advertisement's first and second scene where an old man is reading in a park, it's determined that the participants generally have shown a positive attitude. However, despite this situation reflects the positive participation's positive views, in their statements they are taking a critical stance for the scene's negative aspects as being an "unrealistic" scene. It's significant that in the interview it's often stated that it's an unrealistic view in this context

In the research, the participants' attention for the actress turning the pages of the book she's reading in less than one second at the café setting on the third and fourth scene of the book reading themed public spot advertisement has been tested and their views on this subject has been taken. As for the views about this no significant different points of view; positive or negative have been encountered, nobody has realized the situation but just one person, also according to most views the scene wasn't found to be believable and some have overlooked the situation and have ignored it. In this context when the audience's general views have been evaluated, it's been concluded that this situation must be considered and it's determined that the audience largely doesn't realize the logical mistakes in public spot advertisements.

In the research according to the participants' thoughts on the slogans broadcasted at the end of the public spot advertisements; there haven't been significant differences between the positive and negative views, however there has been positive critical approaches that the slogans are successfully conveying the message that's wanted to be given. Among the stated views of the participants' the view that the slogans are irritating is significant in the context of the public spot advertising's functionality being questioned. In the study by Çakır \& Çakır (2007) it's been concluded that there are no significant differences towards the advertising being irritating and deceptive. When this situation includes the statement that the participant's conscience is hurt, the thoughts towards the slogans given in the public spot advertisements include the elements of emotional exploitation is strengthened. Shanahan, Hopkins, \& Carlson (2010), are stating that shock elements and/or appeals may give discomfort. We can give these suggestions for application that will increase effectiveness of public spot advertisements in the context of lifelong learning and the future researches according to the findings as the result of this research: Studies should be made in order to increase the quality of produced public spot advertisements in the eyes of the audience. Studies should be conducted to analyse the public spot advertisements' signs from the angle of the audience perception. More public spot advertisements should be produced in the theme of education and social awareness raising works should be conducted on this subject.

\section{References}

Aytekin, H. (2016). Görsel-işitsel medyada sağlık—güvenlik halleri: tartışılması gereken bir alan olarak kamu spotu. Selçuk Iletişim Dergisi, 9(3), 249-275. Retrieved from http://josc.selcuk.edu.tr/article/view/5000176088

Çakır, V., \& Çakır, V. (2007). Televizyon reklamlarının algılanan değeri ve reklam tutumu ilişkisi: bir yapısal eşitlik modeli. İstanbul Üniversitesi İletişim Fakültesi Hakemli Dergisi, (30), 37-58.

Duyan, V., Kapısız, S. G., \& Yakut, H. İ. (2013). Doğum öncesi bağlanma envanteri’nin bir grup gebe üzerinde Türkçe'ye uyarlama çalışması. The Journal of Gynecology-Obstetrics and Neonatology, 10(39), 
$1609-1614$.

Elden, M. (2009). Reklam ve reklamcillk. İstanbul: Say Yayınları.

Elferd, M. (2015). UNESCO, the Faure Report, the Delors Report, and the political utopia of lifelong learning. European Journal of Education, 50(1), 88-100. https://doi.org/10.1111/ejed.12104

Ertike, A. S. (2009). Reklam: Temel kavramlar, teknik bilgiler, örnekler. Ankara: Detay Yayınc1lık.

Güleç, İ., Çelik, S., \& Demirhan, B. (2012). Yaşam boyu öğrenme nedir? Kavram ve kapsamı üzerine bir değerlendirme. Sakarya University Journal of Education, 2(3), 34-48.

Kaptan, S. (1998). Bilimsel Araştırma ve İstatistik Teknikleri (11. Baskı). Ankara: Tek Iş̧ı Web Ofset Tesisleri.

MEGEP (Mesleki Eğitim ve Öğretim Sisteminin Güçlendirilmesi Projesi). (2007). Halkla ilişkiler ve organizasyon hizmetleri: Reklamcllıkta temel kavramlar. Ankara: Milli Eğitim Bakanlığı. Retrieved from http://www.megep.meb.gov.tr

Merriam, B. S. (2013). Nitel araştırma desen ve uygulama için bir rehber. (3. Basım). (Çev. F. Koçak Canbaz, M. Öz., S. Turan). Ankara: Pegem Akademi Yayınları.

Shanahan, J. K., Hopkins, C. D., \& Carlson, L. (2010). The Unintended Consequences of Using "Posers" in Nonprofit Public Service Announcements and Proposed Self-Regulatory Disclosure Solutions. Journal of Public Policy \& Marketing, 29(2), 219-231. https://doi.org/10.1509/jppm.29.2.219

Steffens, K. (2015). Competences, learning theories and MOOCs: Recent developments in lifelong learning. European Journal of Education, 50(1), 41-59. https://doi.org/10.1111/ejed.12102

Stokes, N. C., \& Hull, M. M. (2002). Every drop counts: students develop public service announcements on the importance of water conservation. The Science Teacher, 69(5), 40-41.

Tayfur, G. (2008). Reklamcılık (3.Baskı). Ankara: Nobel Yayın Dağıtım.

The World Bank. (2003). Lifelong learning in the global knowledge economy: Challenges for developing countries, A World Bank report. Washington: The International Bank for Reconstruction and Development, The World Bank. https://doi.org/10.1596/978-0-8213-5475-9

Tower, K. (2000). In our own image: shaping attitudes about social work through television production. Journal of Social Work Education, 36(3), 575-585.

Yaman, F., \& Göçkan, İ. (2015). Kamu spotu reklamlarının sigara kullanıcıları üzerindeki etkisi: Afyonkarahisar ilinde bir uygulama. KAÜ IIBF Dergisi, 6(11), 53-66.

Yıldırım, A., \& Şimşek, H. (2014). Sosyal bilimlerde nitel araştırma yöntemleri (8 basım). Ankara: Seçkin Yayıncilik.

\section{Copyrights}

Copyright for this article is retained by the author(s), with first publication rights granted to the journal.

This is an open-access article distributed under the terms and conditions of the Creative Commons Attribution license (http://creativecommons.org/licenses/by/4.0/). 